\title{
Government Spending and Real Exchange Rate Case of Albania
}

\author{
Edmira Cakrani*1 ${ }^{1}$ Pranvera Resulaj ${ }^{1}$, Luciana Koprencka(Kabello) ${ }^{1}$
}

\begin{abstract}
:
Various studies have found that government spending can lead to overestimation or underestimation of the real exchange rate, depending on the composition of these expenditures. The purpose of this paper is to assess the impact of government spending on real exchange rate in Albania. In this paper is used a log liner model with quarterly data. Other explanatory variables in this model are: foreign direct investment, remittances, real GDP per capita, openness. Variables are tested for unit root and cointegration. The results indicate that government spending is associated with overvaluation of real exchange rate in Albania.
\end{abstract}

JEL Classification: E62; F31.

Keywords: Government spending, real exchange rate, unit root, cointegration.

\section{Introduction}

Real exchange rate is one of the most important macroeconomic variables and its management poses a challenge for policymakers. Its change affects the broad allocation of resources in the economy, between tradable and non-tradable products. Real exchange rate is considered also as a key indicator of a country's competitiveness. A real overvaluation of the exchange rate is interpreted as a decline in price competitiveness, while a real exchange rate undervaluated leads to a faster economic growth (Rodrik, 2008). A real exchange rate consistently overestimated is an early indicator of possible currency crisis (Kaminsky and Reinhart, 1999). In a study on Albania, Mancellari and others (1999) showed that changes in the exchange rate precede inflation. Exchange rate fluctuations in developing countries can affect aggregate demand and investment expansion (Frenkel, 2004), while an overvalued currency negatively affects employment (Hua, 2011).

The strategic objective of Albania is the accession to the European Union, where the last stage of this process is the monetary union. This union requires as precondition the exchange rate stability, at a rate, which should reflect the best

${ }^{1}$ University of Vlora "Ismail Qemali"

*Corresponding Author 
possible assessment of the equilibrium exchange rate, based on a wide range of economic indicators $(\mathrm{ECB}, 2003)$. Therefore, the main objective of policy rate should be correction of the real exchange rate misalignment.

In literature, real exchange rate is seen as a function of basic macroeconomic variables. One of these variables is government spending. The volume and composition of government spending affect the value of the real exchange rate, depends on whether these purchases are mainly in tradable or non tradable products. If these purchases are made in non tradable products, then it may be associated with overestimation of the real exchange rate. Instead, if these purchases are mainly in tradable products, then this may lead to the deterioration of the trade balance due to increased imports, resulting in an underestimation of the real exchange rate. So, the effect of government spending on the real exchange rate is unclear. This is supported by empirical studies, which though on this topic are scarce. These studies have shown that government spending can be associated either by an undervaluation or overvaluation of the real exchange rate. In one of the earliest studies, Edwards (1989) found that increasing government expenditure induced a real exchange rate appreciation for 12 developing countries. Ravn and others (2007) investigated the effect of government spending shocks for some industrial countries. Using panel structural VAR analysis they found that an increase in government purchases leads to an expansion in output and private consumption, a deterioration in the trade balance, and a depreciation of the real exchange rate. Benetrix and Lane (2009), studied the effects of government spending shocks in eleven EMU countries. Their study shows that shocks in these spending tend to produce real depreciation in countries that are characterized by floating exchange rate regimes. Caputo and Fuentes (2012) estimate a relationship between the RER and its fundamentals for a set of countries from 1980 to 2009. Besides considering the impact of government consumption on the RER, they assess the impact of the other two components of fiscal expenses, government transfers and investment. Their results suggest that in developed countries, changes in both government transfers and public investment do not generate a significant change in the RER. For developing economies, however, they conclude that government transfers tend to appreciate the RER, whereas government investments tend to depreciate it. For both set of countries, government expenditures tend to appreciate the RER, although the impact is comparatively larger in developing economies. In another study, Galstyan and Lane (2009) used a 2 sector model for a small open economy for some OECD countries. They showed that the composition of government spending influences the long-run behavior of the real exchange rate: an increase in government consumption is associated with real appreciation, while an increase in government investment 
may generate real depreciation. Their empirical work confirms that government consumption and government investments have different effects on the real exchange.

Government expenditures represent an important component of GDP in Albania. Their level since 2000 has been steadily increasing. They have grown from $9.5 \%$ of GDP in 2000 to $10.7 \%$ of GDP in 2010, with the highest level in 2004 to $11 \%$ of GDP. Current expenditures constitute the great part of government spending. But, their trend has been irregular. Initially, the level of current expenditures has made up to $78.1 \%$ of total government expenditures. In 2003, this level was $84.3 \%$ of total government expenses. Later, their level has decreased, while in 2008 have accounted for $71.2 \%$ of total government expenditure.

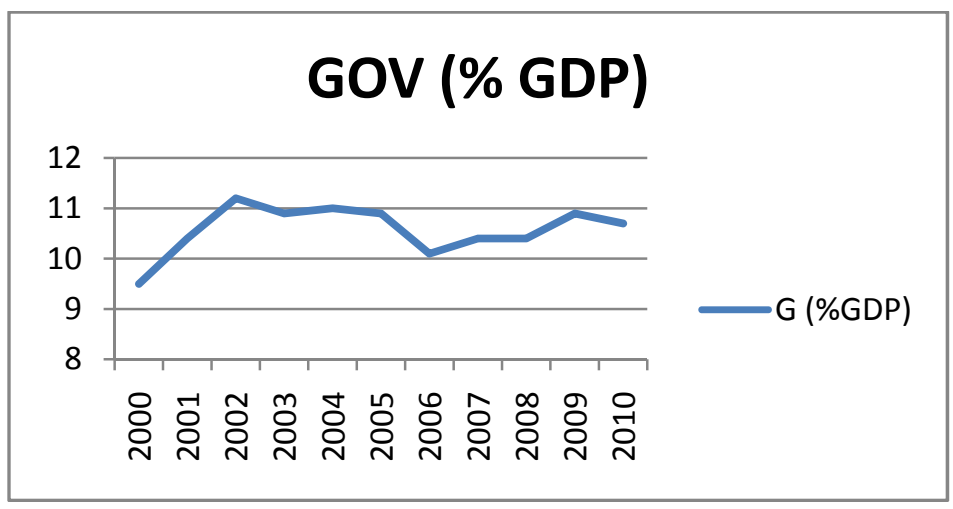

Figure 1: Government spending as \% of GDP. (Ministry of Finance, Albania)

The objective of this paper is to study the possible effects of government spending on real exchange rate in Albania. Since Albania's main trading partners are Italy, Greece and Germany, in this paper the real effective exchange rate will be constructed against the euro. Due to lack of data, the study will include the period 2004-2011 with quarterly data.

\section{Model specification}

In this study the real effective exchange rate will be calculated as a weighted geometric average of the price index of partner countries compared to domestic prices.

$\mathrm{RER}=\mathrm{E} \frac{P^{*}}{P}=\prod_{i=1}^{I}\left[S_{i} \frac{P_{i}^{*}}{P}\right]^{w^{i}}$

Where $S_{i}$ is the nominal exchange rate between euro and Albanian lek is, $P_{i}^{*}$ is the price level of the $i^{\text {th }}$ country and $W_{i}$ is the weight corresponding to 
the $i^{\text {th }}$ trade partner. According to this definition, a fall in the index will show a real overvaluation, and a increase will show a real depreciation of the domestic currency.

Besides government expenditures, as explanatory variables in the model will be included:

Trade openness (OPEN), defined as the sum of exports and imports in relation to GDP. An increase in trade openness is considered as an indicator for reducing the trade restrictions. The aim of trade restrictions is the protection of domestic products. Reducing trade restriction, domestic products prices are expected to fall, leading to a depreciation of the RER. So, an increase in trade opening leads to the devaluation of the RER.

Foreign Direct Investment (FDI) in relation to GDP will be used as a measure of financial globalization, as suggested by Xing and Zhang (2004). Elbadawi (1994) showed that an increase in inflows in the long run will result in appreciation of the real exchange rate in the long run. Elbadawi (1994) also showed that even in the short-term, inflows tend to be associated with the overvaluation of the real exchange rate in comparison with its value in the long run. Thus, foreign direct investments have negative effect on the real exchange rate.

Remittances (REM) in relation to GDP: their effect on the real exchange rate is unclear. Remittances represent additions to the household income level. This will be accompanied by increasing demand for tradable and non-tradable products. While the prices of tradable products are determined in the world market, an increase in demand in the non-tradable sector will be accompanied by an increase in their price, to turn this sector again in balance. Thus, a relative increase in the price of non-tradable to tradable will lead to real exchange rate appreciation. Moreover, higher prices in this sector will lead to an increase in the supply in this sector, by transferring resources from the tradable sector to the non-tradable sector, reducing its activity. Reduced tradable sector activity will lead to falling exports and rising imports. Thus the trade balance will deteriorate and the real exchange rate will depreciate.

Real income per capita (GDP/c): Higher-income countries have higher price levels. This effect is known as "Penn Effect" (Summers and Heston, 1991). This means that there is a positive correlation between per capita real income and real exchange rate.

All the above variables will be used in the logarithm form. The data were obtained from Bank of Albania, WDI, Ministry of Finance, Albania.

Considering these factors as determinants of the level of the real exchange rate and the expected impact of each of them, we can write the equation 


$$
\begin{aligned}
& +\quad+/-\quad+\quad-+/- \\
& \text { RER }=\mathrm{f}(\mathrm{OPEN}, \mathrm{REM}, \mathrm{GDP} / \mathrm{c}, \mathrm{FDI}, \mathrm{GOV})
\end{aligned}
$$

\section{Econometric estimation}

In this study will be used the cointegration method to explain the possibility of long-term relationship between economic variables. Time series data will be tested to see if they are covariance stationary (i.e. no trend) or are stationary trend. This will be done through Augmented Dickey-Fuller test (ADF). If the exchange rate is not stationary, any stationary variable cannot be a determining variable because variables determining the exchange rate in the long run should have the same order of integration, as the exchange rate.

Table 3. 1: Summary of Unit Root Test

\begin{tabular}{|l|l|l|l|}
\hline Variable & ADF Test & p-value & Decision \\
\hline rer & -5.028596 & 0.0004 & Stationary \\
fdi & -3.239964 & 0.0285 & Stationary at 5\% \\
gdp/c & -3.597171 & 0.0124 & Stationary at 5\% \\
open & -6.367360 & 0.0000 & Stationary \\
rem & -8.580327 & 0.0000 & Stationary \\
gov & -3.031379 & 0.0468 & Stationary at 5\% \\
\hline
\end{tabular}

Critical Values:

\begin{tabular}{|l|l|l|l|}
\hline & $1 \%$ Critical Value & $5 \%$ Critical Value & $10 \%$ Critical Value \\
\hline ADF Test & -3.689 & -2.971 & -2.625 \\
\hline
\end{tabular}

The test shows that FDI, GDP/c and GOV are not stationary, but become stationary after taking the First Difference. Thus, to eliminate the problem of stationary, variables should be included in the model in the first difference. Cointegrating Test: This test serves to identify the possibility of a long-term relationship between real exchange rate and the fundamental variables determining the real exchange rate.

The table 2 shows the results of cointegration test by using Johansen methodology. The result indicates rejection of the null hypothesis of lack of cointegration between variables and the existence of a cointegration equation in $5 \%$ level. So variables have long-term relationships between them. 
Table 3. 2: Result of Johansen Cointegration Test

\begin{tabular}{ccccc}
\hline $\begin{array}{c}\text { Hypothesized } \\
\text { No. of CE(s) }\end{array}$ & Eigenvalue & $\begin{array}{c}\text { Trace } \\
\text { Statistic }\end{array}$ & $\begin{array}{c}0.05 \\
\text { Critical Value }\end{array}$ & Prob. $^{* *}$ \\
\hline \hline None ${ }^{*}$ & 0.8599 & 137.74 & 125.61 & 0.0074 \\
At most 1 & 0.7604 & 84.667 & 95.753 & 0.2263 \\
At most 2 & 0.4716 & 46.080 & 69.818 & 0.7946 \\
At most 3 & 0.4349 & 28.855 & 47.856 & 0.7752 \\
At most 4 & 0.2965 & 13.440 & 29.797 & 0.8705 \\
At most 5 & 0.0723 & 3.9444 & 15.494 & 0.9080 \\
At most 6 & 0.0685 & 1.9172 & 3.8414 & 0.1662 \\
\hline
\end{tabular}

Trace test indicates 1 cointegrating eqn(s) at the 0.05 level

* denotes rejection of the hypothesis at the 0.05 level

**MacKinnon-Haug-Michelis (1999) p-values

The cointegration vector in the equation form can be presented as:

LNRER=1.3-0.76LNFDI-0.24LNGOV-0.0001LNOPEN - 0.25LNREM + 0.002LNGDP/c

We can see that trade openness and real income per capita are insignificant variables in our model. While an increase in Foreign Direct Investment appreciates real exchange rate. The coefficient is not very high: a $1 \%$ increase in FDI leads to real appreciation by $0.76 \%$. In terms of government spending, even though the coefficient in not high, we can say that $1 \%$ increase in government spending leads to real appreciation by $0.24 \%$. Similarly, a $1 \%$ increase in remittances lead to an estimation by $0.25 \%$ of the real exchange rate.

\section{Conclusions}

This paper analyzed the effect of government spending on real exchange rate in Albania. The volume and composition of government spending can affect real exchange rate in two directions: overvaluating or undervaluating it. Government spending represents approximately $10 \%$ of GDP in Albania. In this paper, real exchange rate is determined as dependent variable, with government spending, foreign direct investment, openness, remittances and real GDP per capita as explanatory variables. Initially variables were tested for unit root. Some of the variables resulted stationary of order zero $\mathrm{I}(0)$, while the rest resulted stationary of the first order $\mathrm{I}(\mathrm{I})$. To eliminate the problem of stationary, variables were entered in model in the first difference, then (I). Stationary variables were tested for cointegration: the possibility of the existence of a long-term relationship between them. The test showed the existence of an integration equation at $5 \%$. 
The regression equation showed that government spending in Albania is associated with the overvaluation of real exchange rate, even the coefficient is not very important. This poses a challenge for the Albanian government, because the overvaluation of the real exchange rate means that the country loses competitiveness of its products.

\section{References}

Benetrix, A.S., P. R. LANE, (2009a). Fiscal Shocks and the Real Exchange Rate. IIIS Discussion Paper No. 286.

ECB (2003). Policy position of the Governing Council of the ECB on Exchange Rate Issues Relating to the Acceding Countries. European Central Bank, Frankfurt am Main (18th December 2003).

Edwards, S. (1989). Real exchange rates, devaluation, and adjustment: Exchange rate policy in developing countries. Cambridge, $M A$. The MIT Press.

Elbadawi, A.L (1994). Estimating Long Run Equilibrium Real Exchange Rate. Institute for International Economi. Washington D.C.

Frenkel, R.,(2004). Real Exchange Rate and Employment in Argentina, Brazil, Chile, and Mexico. Paper prepared for the Group of 24, Washington, D.C. September

HUA Ping,(2011). The economic and social effects of real exchange rate_ Evidence from the Chinese provinces. INTERNATIONAL CONFERENCE ON SOCIAL COHESION AND DEVELOPMENT,2011, Paris, France OECD Development Centre.

Kaminsky Graciela L. \& Carmen M. Reinhart, (1999).The twin Crises:The causes of banking and balance of Payments Problems. American Economic Review. American Economic Association, vol. 89(3), pages 473-500, June.

Mancellari, A.,Mytkolli, H.,Kola T.,(1999).Exchange rate and Economic transition.

Ravn Morten O., Stephanie Schmitt-Grohe, Martin Uribe.(2007). Explaining the Effects of Government Spending Shocks on Consumption and the Real Exchange Rate" NBER Working Paper No. 13328.

Rodrigo Caputo, Miguel Fuentes,(2012). Government Spending and the Real Exchange Rate: a Cross - Country Perspective. Working Papers of the Central Bank of Chile $\mathrm{N}^{\circ} 655$.

Rodrik, Dani.( 2008). The Real Exchange Rate and Economic Growth: Theory and Evidence. Brookings Papers on Economic Activity, Fall Conference Draft.

Summers.Robert and Heston.Alan,(1991).The Penn World Table: An Expanded Set of International Comparisons, 1950-1988. The Quarterly Journal of Economics, MIT Press, vol. 106(2), pages 327-368, May.

Vahagn Galstyan, Philip R. Lane.(2009). The Composition of Government Spending and the Real Exchange Rate. Journal of Money, Credit and Banking. Volume 41, Issue 6, pages 1233-1249.

Xing, Y. and Zhang, K.H (2004). FDI and Regional Income Disparity in Host Countries: Evidence from China Economia Internazionale Volume LVII, No. 3 - August 2004 
